\title{
ДВЕ ЦРКВЕ ОСМАНСКОГ ДОБА ИЗ ЗАПАДНЕ СРБИЈЕ
}

\author{
Дејан Булић \\ Историјски институт, Београд
}

\begin{tabular}{r|r} 
e-mail: gavbulic@yahoo.com & Оригинални научни рад \\
Примљено: 6. 5. 2020. & УДК: 904:726(497.11)"16" \\
Прихваћено: 31. 7. 2020. & $902.2(497.11-15) " 2018 ”$
\end{tabular}

\begin{abstract}
Апстракт: Током 2018. године Историјски институт је археолошки истражио две иркве из османског доба. Прва је ирква из села Заглавак, надомак Бајине Баште, где је на локалитету Орашаи истражена једнобродна грађевина правоугаоне основе са полукружном апсидом на источној страни. На основу археолошких истраживања и помена свештеника у Рачанском поменику, ирква би била изграђена пред последюу деценију 17. столећа, а страдала већ у Великој сеоби 1690. године. Црква је грађена традииионалном техником, у духу народног градитељства, уз употребу ломьеног камена и иловаче као везива, што указује на локалног ктитора и локалне мајсторе. Друга ирква се налази у селу Сивчина, локалитет Баре, на десетак километара западно од Ивањице. Црква брвнара је једнобродна грађевина, спољних димензија 9,40 x 5,20 м. Према археолошким истраживанима, аналогијама и надгробницима који је окружују, ирква је датована у другу половину 17. столећа. Обнова пода цркве у два наврата сведочи о њеним страдањима, а коначан крај видимо у годинама слома Првог српског устанка, када су и бројне иркве у околини страдале.
\end{abstract}

Кључне речи: Западна Србија, Заглавак, Сивчина, османско доба, ирква, 17. век, Бајина Башта, Ивањица

Османска епоха и трагови материјалне културе овог доба доскора нису привлачили пажњу наших археолога. Због релативно блиског периода, с једне стране већина истраживача је имала осећај да залази у сферу интересовања етнолога, а с друге стране овај период је сматран недовољно атрактивним и вредним за изучавања и као област која одвлачи пажњу од важнијих тема. Ситуација је почела да се мења када се схватило да се преко података из османске епохе може боље сагледати и средњи век и доћи до важних информација, које нам због мањка средњовековних извора измичу.

Ретка је била пракса систематског ископавања, а самим тим и објављивања радова о цркавама из османског доба. Усмерених истраживања на локалитете ове епохе готово да није ни било, што само указује на недовољну истраженост западне Србије. Најчешће су споменици ове епохе били предмет интересовања тек узгред, када су поједини истраживани локалитети - нај- 
чешће цркве и манастири - имали и слојеве из овог времена: Св. Ахилије у Ариљу (Цуњак и Јордовић, 1982, 231-241; Чанак-Медић, 2002, 1- 355), Бела Црква Каранска (Цветковић-Томашевић, 1992, 159-176; Ђорђевић, 1996, 104 107), или су истраживања била малог обима, вођена због архитектонских или конзерваторских радова: манастир Ковиље на Јавору (Тошић, 1997, 96-97) или црква у Брезови (Станић, 1993, 97-145; Ивковић и Ђокић, 1988, 317-318). На списку интересовања археолога нашла се тек понека црква: Црквина-Савинац (Мандић и др., 2002, 13-20), остаци рачанског скрипторија (Јанковић и Праштало, 2008, 143-145) или већ уништени рујански манастир (Вукадин и Ивковић, 1987, 81-89). С друге стране, поједина археолошка истраживања никада нису публикована - црква у Високој код Ариља, или нису публикована у целости, као што је случај са Ужичким градом (Поповић, 1995, 1-166).

Изучавање прошлости западне Србије, односно некадашње земље Моравице, водило нас је и кроз мања тематска рекогносцирања појединих њених делова. Тако се десило да се 2018. године приликом рекогносцирања Ивањице, региструју цркве у Сивчини и Заглавку, за чије су истраживање интересовање показали и мештани ова два села. Спој интересовања мештана са научном знатижељом резултирао је истраживањима ове две цркве које публикујемо у овом раду. Иако без атрактивне архитектуре и више него скромних налаза, ипак завређују пажњу. Чињеница да су обе грађевине истражене исте године навела нас је да у оквиру једног рада обухватимо обе грађевине. На овај начин је лакше сагледати околности под којима су се дизале црквене грађевине у османско време, као и који су облици народног градитељства примењивани за њихову изградњу.

\section{Црква у Заглавку}

Прва црква је из села Заглавак подно Кадињаче, уз реку Дервенту у Златиборском округу, надомак Бајине Баште. До сада у селу није забележен нити један археолошки локалитет, први засад познати помен у историјским изворима је у османском попису овчарине и торовине у кадилуку Сребреница из 1596. године, када је у селу уписано 3.745 оваца. ${ }^{1}$ Материјалне трагове вредне спомена нису забележили ни истраживачи народних старина. Тек у једној краткој оцени етнолог Љуба Павловић забележио је као доказ старине села стара гробља у Дервенти и на Јаворини, старе ископине на изворишту

\footnotetext{
${ }^{1}$ Извор се налази у Османском архиву Председништва државних архива Председништва Републике Турске у Истанбулу и чини део архивске серије Kâmil Kepeci, група дефтера Mevkufat Kalemi Ganem Kitabeti No 3949. Захваљујем на податку др Драгани Амедоски из Историјског института.
} 
Дервенте и стара огњишта по планинама... На другом месту пак поменуо је Црквину на Орашцу, али у погрешном контексту постојања старог гробља (Павловић 1930, 328, 397). Село је било познато једино по кући и надгробном споменику соколског кнеза Николе Новатовића. ${ }^{2}$

Међутим, помињани топоним Црквина, данас обрастао у растиње и шуму, постао је предмет интересовања Историјског института. ${ }^{3}$ Утврђено је да се на поменутој локацији налазе остаци мањег објекта (приближне површине 10 × 10 м), за који мештани држе да је црква. Начињен је договор да се постојећи локалитет ослободи растиња, сондажно истражи, утврди његов габарит, првобитна намена и време градње.

Археолошка истраживања обављена су у периоду од 20. јула до 4. августа 2018. године на локалитетима Црквина ${ }^{4}$ и Орашац-Звонара, ${ }^{5}$ оба у засеоку Деспотовићи. ${ }^{6}$ На локалитету Црквина, показало се, после сондажног истраживања, да не постоје остаци цркве, већ остаци једне профане грађевине, зидане уз употребу блата као везива, потпуно у духу народног градитељства овог краја. Много индикативнији био је локалитет Орашац, удаљен свега неколико стотина метара од прве локације, на коме се по традицији налазила звонара цркве. Локалитет се налазио на гребену, данас обраслом у шуму. Гребен је некада био поред трасе пута Бајина Башта (преко Дуба) - Ужице (преко Јелове Горе) - Пожега - Косјерић и својевремено имао отворен поглед ка селима Церју и Варди.

Beћ се у конфигурацији терена назирало постојање овалног објекта, приближне оријентације исток-запад, са заобљеном источном страном, која је индицирала постојање апсиде, односно цркве. ${ }^{7}$ Делимично видљиви

\footnotetext{
${ }^{2}$ Кућа је из друге деценије 19. столећа, али иако под заштитом Завода за заштиту споменика културе, препуштена је пропадању.

${ }^{3}$ Сеоска општина Заглавак обратила се Историјском институту са жељом да се поменути локалитет истражи, а затим према условима Завода за заштиту споменика културе Краљево на том месту постави спомен-плоча са именима погинулих мештана у Великом рату.

4 Локалитет Црквина налази се на шумском газдинству Бајина Башта, број парцеле 425, к. о. Бајина Башта.

5 Локалитет се налази на шумском газдинству Бајина Башта, број парцеле 405/I, к. о. Бајина Башта.

${ }^{6}$ Комплетне материјалне трошкове истраживања на име радова које је извео Историјски институт, смештаја екипе и трошкова на име физичке радне снаге, сносила је МЗ Заглавак, општина Бајина Башта. Археолошка истраживања је водио археолог др Дејан Булић, научни сарадник Историјског института - Београд, док су део стручног тима чиниле: Радмила Јочић, археолог Народног музеја из Ужица, и Аница Јанковић, студент археологије, такође из Ужица. Цркву је технички снимио Александар Матовић, архитектонски техничар Завода за заштиту споменика из Краљева.
}

${ }^{7}$ Истраживању је претходило крчење простора предвиђеног за археолошка истраживања и уклањање неколико стабала. 


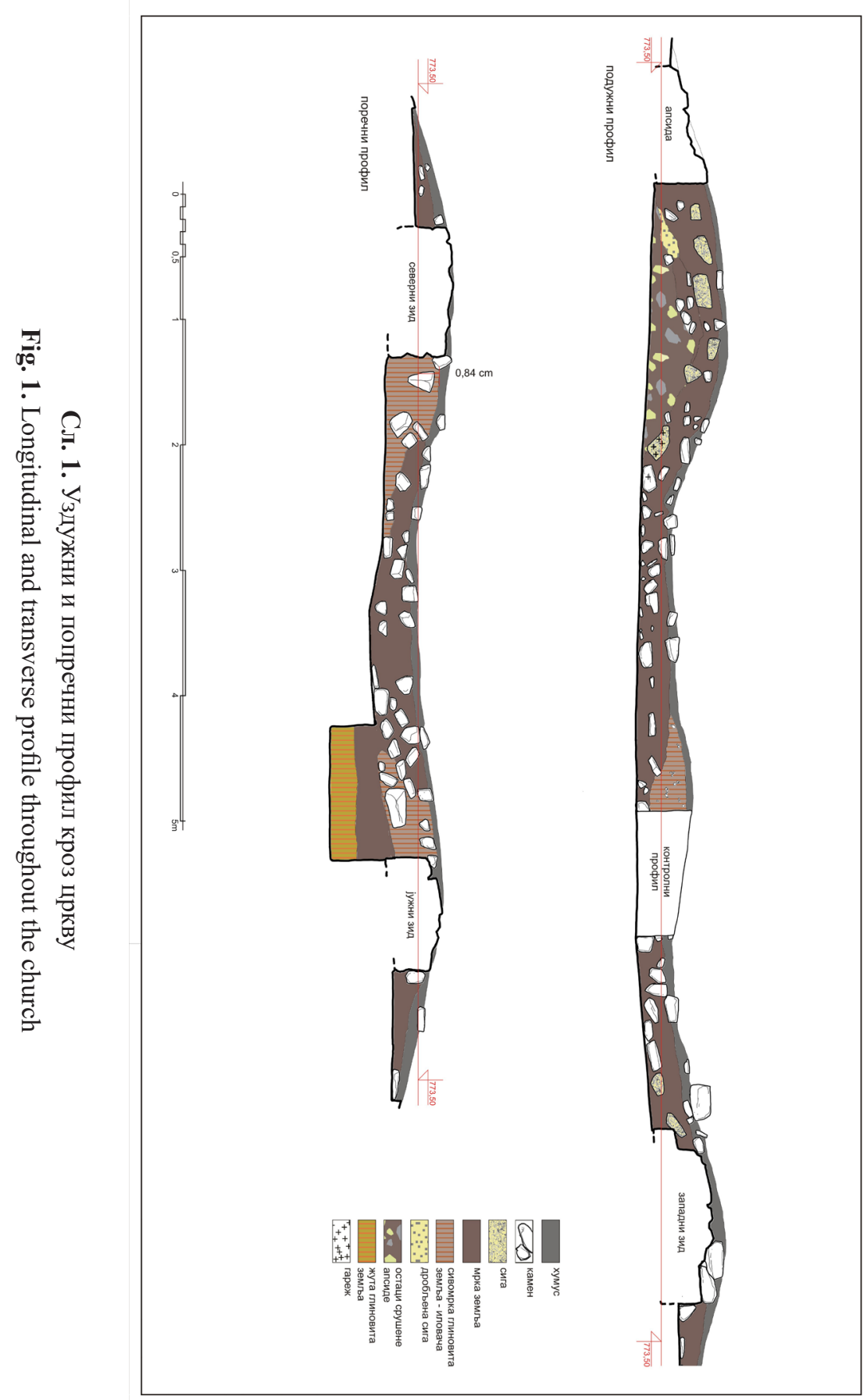




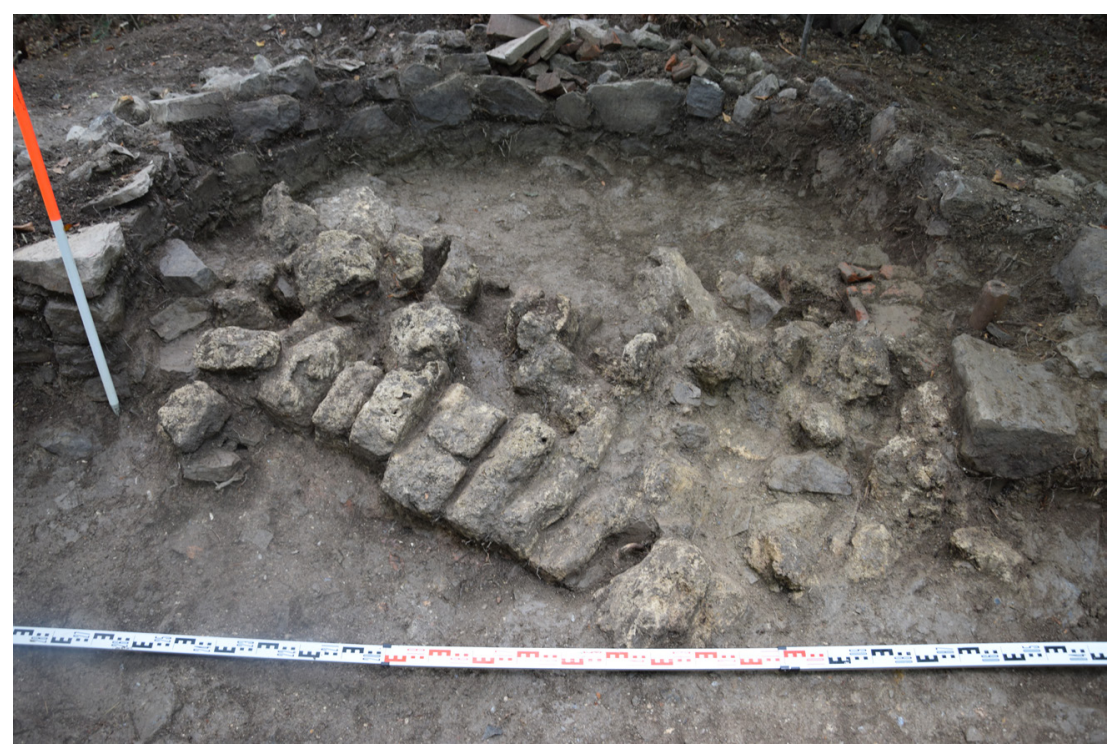

Сл. 2. Обрушена полукалота у апсиди

Fig. 2. Crushed semi-calotte in the apse

остаци објекта подељени су на две приближно једнаке половине осом западисток. У источном делу ископа са северне стране ове осе, постављена је најпре ров сонда, ширине 1,30 м и дужине 4 м, којом се желела пресећи претпостављена апсида објекта. Након што је унутар укопа уочено унутрашње лице апсиде, уследило је његово праћење ка северу, да би накнадно цела ова површина североисточног дела цркве била обухваћена јединственим ископом.

Са два контролна профила осом исток-запад ширине 0,5 м и осом север-југ, ширине 1 м, црква је подељена на 4 квадрата (сл. 1). Приликом уклањања хумуса (тамномрка земља и лишће) и присутног камена пронађене су релативно бројне чауре од муниције. ${ }^{8}$ Следио је слој мрке земље са бројним камењем различите величине, уломцима сиге и спорадичним уломцима кровне опеке. Унутар апсидалног дела констатована је агломерација сиге, која је представљала обрушену полукалоту апсиде (сл. 2). Такође је само овде уз унутарње лице апсиде пронађено неколико уломака античке кровне опеке типа тегула (сл. 3). Измерене дебљине тегула износе: 3,5-4 цм код очуваних димензија: 14 х 14,5 цм; 26 х 18,5 цм и 20 х 13 цм, док је висина руба 5,5-6 цм, а дебљина руба: 2,5; 3,5 и 4 цм. Никаквих других налаза или остатака грађевинског везива није било.

\footnotetext{
8 Због некадашње отворености простора и доброг прегледа околног терена око цркве, а изгледа и унутар ње, овде је било ситуирано митраљеско гнездо, а нешто ниже на северној падини још један пешадијски ров.
} 

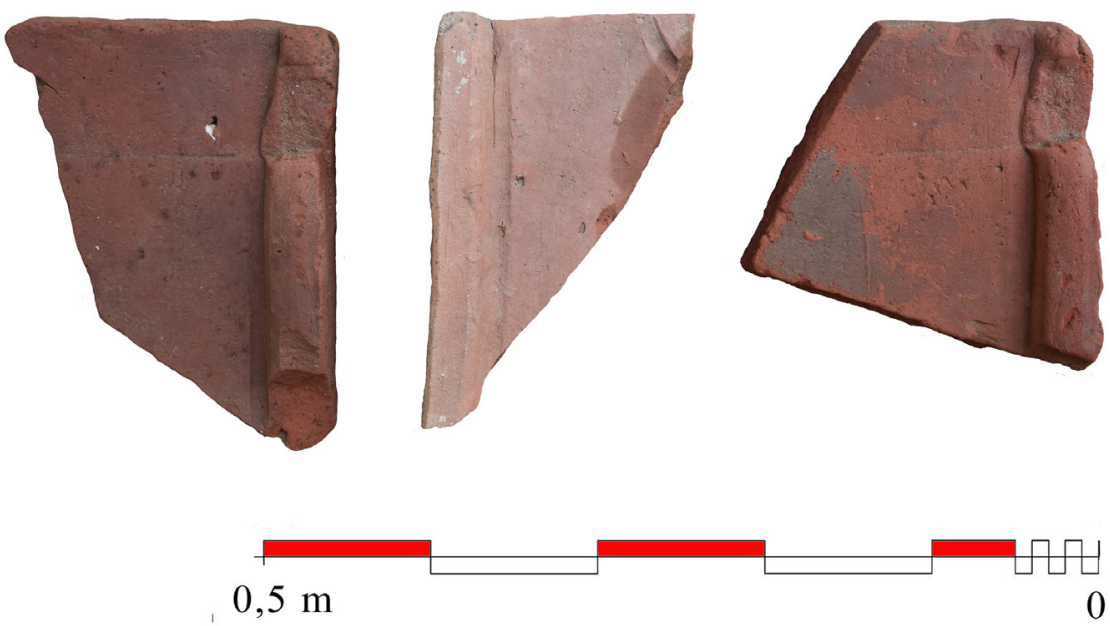

Сл. 3. Налази тегула

Fig. 3. Findings of tegulae

\section{Црквени храм}

Црква представља једнобродну грађевину правоугаоне основе са полукружном апсидом на источној страни. Спољне димензије цркве износе 9,60 х 6 м, односно 7,96 х 4,17 м, колико износе унутрашње мере (Т. 1). Грађена је скромно и немарно, локалним, ломљеним каменом, без постојања правилних редова. Пажљиво је зидан једино унутрашњи спој апсиде и северног рамена цркве. Као везиво коришћена је искључиво жута иловача, без додатака малтера. Очуваност зидова износи од једног реда камена (око 0,20 м) до максимално очуване висине од три до четири реда камена или 0,69 м.

Због такве технике зидања и недовољно чврстог везива, те пада терена са северне и јужне стране, зидови нису сачували у потпуности правце пружања, већ је долазило до њихове дилетације и нагињања делова зида према паду терена. На такво стање зидова утицале су и атмосфералије, а нарочито корење околног растиња, због којег се јужни део западног зида готово потпуно обрушио. Због свега наведеног ширина зидова је променљива и износи: западни зид око 0,77 м; северни зид $0,72-1,05$ м; јужни зид $0,85-0,92$ м, те апсида $0,67-0,77$ м.

Приликом археолошког ископавања није уочен улазни отвор на западном зиду, где се извесно налазио, док висина очуваних зидова цркве није досезала до прозорских отвора. Неколико мањих уломака сиге пронађених уз западни зид цркве омогућавају претпоставку да је архиволт био над улазним вратима, или некакав прозорски отвор изнад њих (сл. 4). 


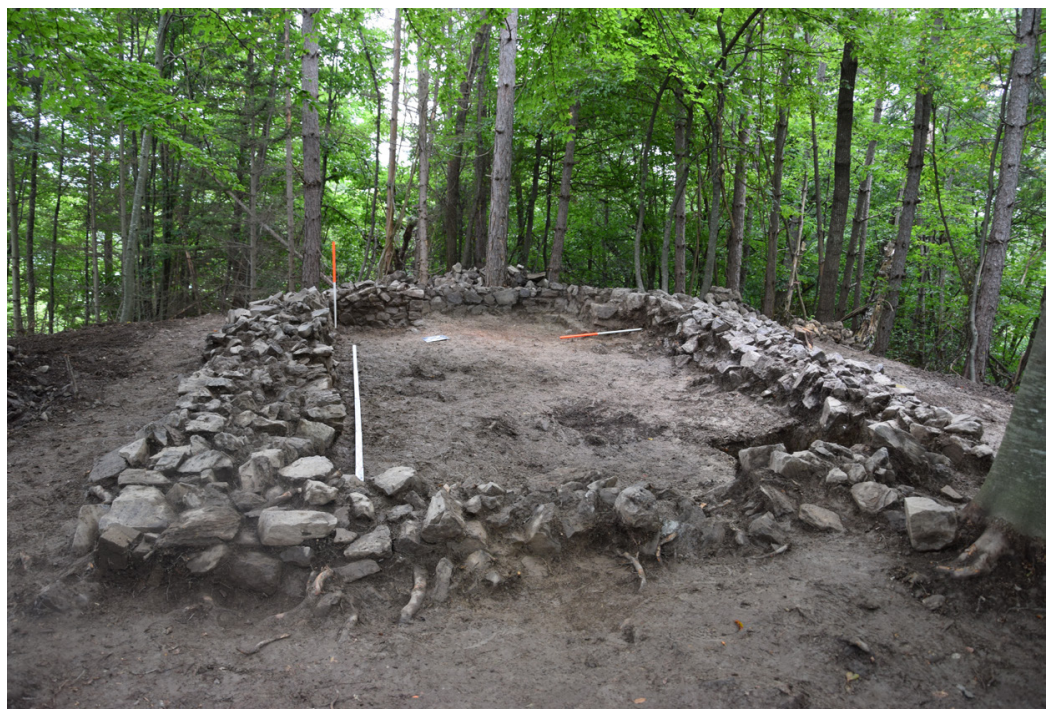

Сл. 4. Основа цркве (снимак са запада)

Fig. 4. Base of the church (photo from the west)

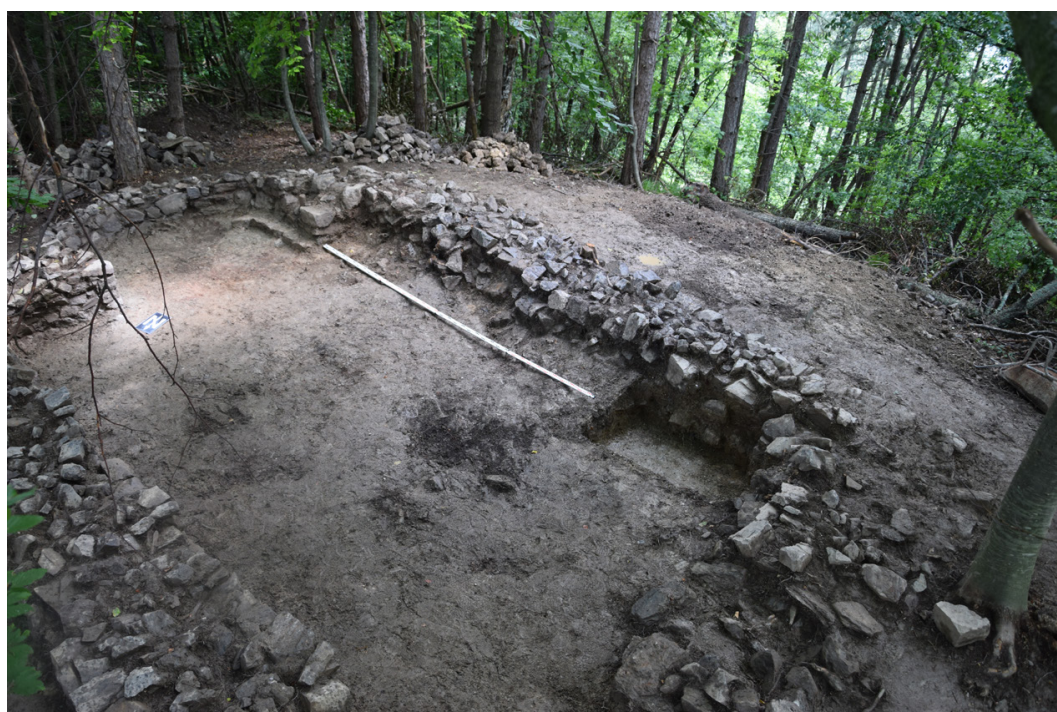

Сл. 5. Основа цркве (снимак са северозапада)

Fig. 5. Base of the church (photo from the north-west)

Под цркве био је од набијене земље. Траг пода сачувао се само у апсиди испод слоја обрушене сиге, где је констатован танак слој глиновите црвенкасте земље. На другим деловима цркве под није уочен, нити се очитавао у контролним профилима (сл. 5). 
Налази уломака сиге сведоче о материјалу од кога је израђена полукалота апсиде, док налази уломака тегула унутар апсиде указују и да је кров овог дела цркве био покривен античким тегулама. На осталим површинама цркве нису пронађени делови кровног покривача, нити било какви метални налази и клинови, што указује на дрвену конструкцију крова изведену на две воде и покривену шиндром уз употребу дрвених клинова. Нису констатовани остаци пиластара или других конструктивних архитектонских елемената; нема налаза секундарне камене пластике и делова црквеног мобилијара.

Због непостојања било каквих покретних археолошких налаза и јасно формираног пода закључено је да је црквени храм био кратко у употреби. На овај закључак указује и околност да се око цркве није формирала некропола, а да је народна традиција локацију цркве заборавила, а Црквину везала за оближњи локалитет.

Како о цркви нема никаквих историјских извора, патрон храма и њен ктитор је остао непознат. Једино је на аустријским картама из 1894. године означена позиција цркве у засеоку Деспотовићи. ${ }^{9}$ Ипак, у то време црква је већ била одавно срушена, јер Љ. Павловић бележи Црквину на Орашцу само као старо гробље, док било какву традицију о цркви не бележи (Павловић 1930, 328, 396). Међутим, у Рачанском поменику село Заглавак помиње се у више наврата уз имена мирјана, а у једном случају наводи се и презвитер Томаш (Поменик манастира Раче 2005, 47a, 64б, 65a, 66а, 69б, 79б, 80б, 82a, 826, 89a, 94б, 98б, 146a, 154a, 162б, 167a, 167б, 169a, 169б). Како се настанак поменика везује за 17. век, односно за период између 1616. и 1682. године, када су забележени најмлађи и најстарији запис, следило би да је црква у Заглавку подигнута током 17. столећа (Руварац 1924, 30-34). У складу са закључцима изнесеним на основу археолошких истраживања, црква је била изграђена пред последњу деценију 17. столећа. Храм је убрзо запустео, након што су у Великој сеоби 1690. године напуштени стари крајеви и становништво се упутило ка северу. У прилог овоме говори и чињеница да у Соколској нахији међу црквама 18. столећа нема помена цркве у Заглавку (Радосављевић 2000, 142). Претпоставка да је градња цркве започета у време Првог српског устанка и да никада није окончана нема основа. ${ }^{10}$

\footnotetext{
9 Tрећа војна мапа Аустроугарске - Zvornik 37-44. Генералне мапе централне Европе, размера 1:200.000, 1913. Извор:https://commons.wikimedia.org/w/index.php?title=Category:3rd Military_Mapping_Survey_of_Austria-Hungary\&filefrom=Reczyca+-+48-52.jpg\#/media/ File:Zvornik_-_37-44.jpg, приступљено 30. 05. 2020 године.

${ }^{10}$ Овоме се противи непостојање било каквог извора из овог доба у вези са њеном градњом, као и чињеница да је Црквина ситуирана на другој позицији, што би било мало вероватно за црквену грађевину из тако блиске прошлости.
} 


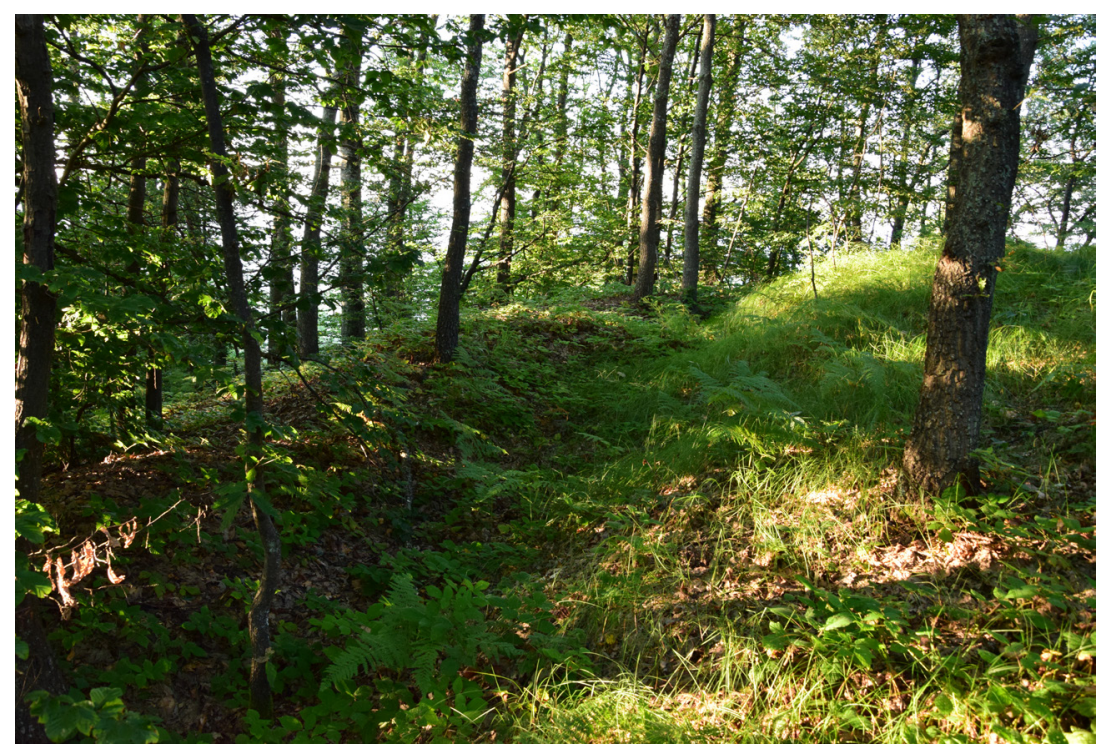

Сл. 6. Локалитет Градина

Fig. 6. The site of Gradina

До сада у атару овог села није забележен нити један археолошки локалитет, међутим, на маргини ових истраживања извршено је и рекогносцирање неколико локалитета у самом селу, индикативног назива.

На граници двају села Злодола и Заглавка налази се брдо Градина, које именом указује на постојање утврђења. Простор је данас зарастао у високу шуму, а површину тла покрива папрат и оструга, због чега није било могуће утврдити да ли има било каквих покретних налаза. На заравњеном платоу видљиви су уски пешадијски ровови и бројни шири овални укопи за артиљеријска оруђа. Међу њима је био један дубљи од осталих, за који држимо да је представљао земуницу за складиштење муниције (сл. 6). На врху овог омањег брда нема видљивих бедема или неких других зидина, што дисквалификује позицију као утврђење из античког или средњовековног времена, али не искључујемо могућу егзистенцију овог брда као праисторијског локалитета.

На омањем брежуљку, сада обраслом у шуму, тик крај асфалтног пута који води у село и на око 1 км од главног магистралног пута за Ужице, налази се мање Грчко гробље (сл. 7). Од некадашњег гробља, које је већим делом искрчено, остала су тек 2-3 мања аморфна усадника и једно улегнуће од гробне раке. Позиција испод овог брежуљка назива се Подгробље, а један део невеликог гробља - сећа се водич Радојко Тимотијевић - својевремено је раскрчен. Споменици су без украса и натписа, и могу се датовати у 17-18. век. 


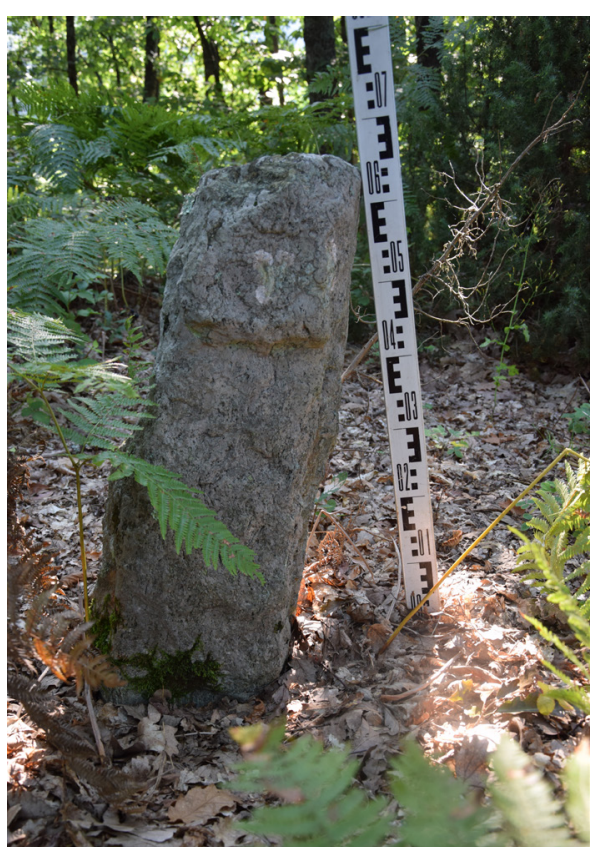

Сл. 7. Локалитет Грчко гробље

Fig. 7. The site of Greek cemetery ("Grčko Groblje")

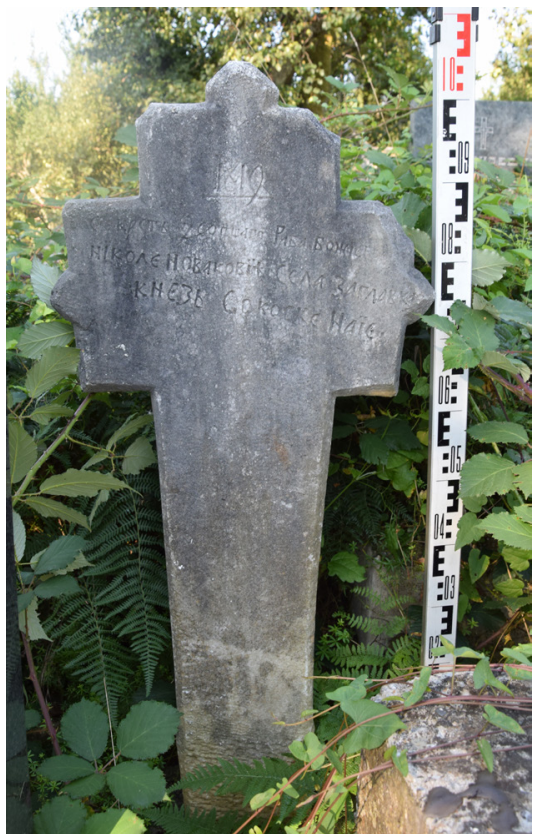

Сл. 8. Надгробни споменик соколског кнеза Николе Новатовића

Fig. 8. Tombstone of the Sokol prince Nikola Novatović

На савременом гробљу у засеоку Стојићи, најстарији сигурно датирани споменик је типичан студенички надгробни крст из 1819. године, који је припадао помињаном соколском кнезу Николи Новатовићу (сл. 8). ${ }^{11}$ На гробљу је видљив и већи број углавном аморфних усадника са уклесаним равнокраким крстом на источној страни - код главе покојника - и без натписа. Припадају 18. веку, али су добрано загазили и у 19. столеће. Присутни су и новији споменици занатске израде, али и поједини крстови од сиге. Може се закључити да је старост гробља око 250 година и да датира из времена досељавања данашњих најстаријих родова у селу.

Захвљујући археолошком ископавању и адекватном документовању остатака сачувано је сведочанство некадашњег постајања цркве у селу Заглавак. Црква је необичне градње за храм, али грађена традиционалном техником и у духу народног градитељства овог краја. Техника градње указује на локалног ктитора и на локалне мајсторе, вероватно из самог села. ${ }^{12}$ Иако

\footnotetext{
${ }^{11}$ Кратку биографију и релевантну литературу о кнезу видети код: Марковић 1999, 398.

12 У селу се и данас могу видети објекти народног градитељства подизани на овај начин, који датирају и из прве половине 20. столећа.
} 
историјски токови нису наменили дуго трајање црквеном храму, због добро познатих и тешких историјских околности, храм представља обележје једног времена, у коме је био подвиг подићи црквени храм, који носи сва обележја народног градитељста од технике градње и материјала, али и скромну економску моћ ктитора и верујућег народа.

\section{Црква у Сивчини}

Друга црква се налази у селу Сивчина, локалитет Баре, на 1.006 метара надморске висине и на десетак километара западно од Ивањице. Са турским освајањем село се нашло на простору Босанског санџака у оквиру нахије Моравица. Управо у то време турске власти подигнута је и ова црква.

У мају 2018. године, након рекогносцирања села Сивчина, на локалитету Баре, у североисточном делу сеоског гробља установљено је постојање остатака цркве. ${ }^{13}$ На тлу су се делимично уочавали северни, јужни зид и апсида на источној страни, док се западни зид могао приближно одредити према осушеном растињу. У источном делу цркве стајала је часна трпеза, чији су камени делови били бетоном везани. Камени под цркве је био прекривен маховином (сл. 9).

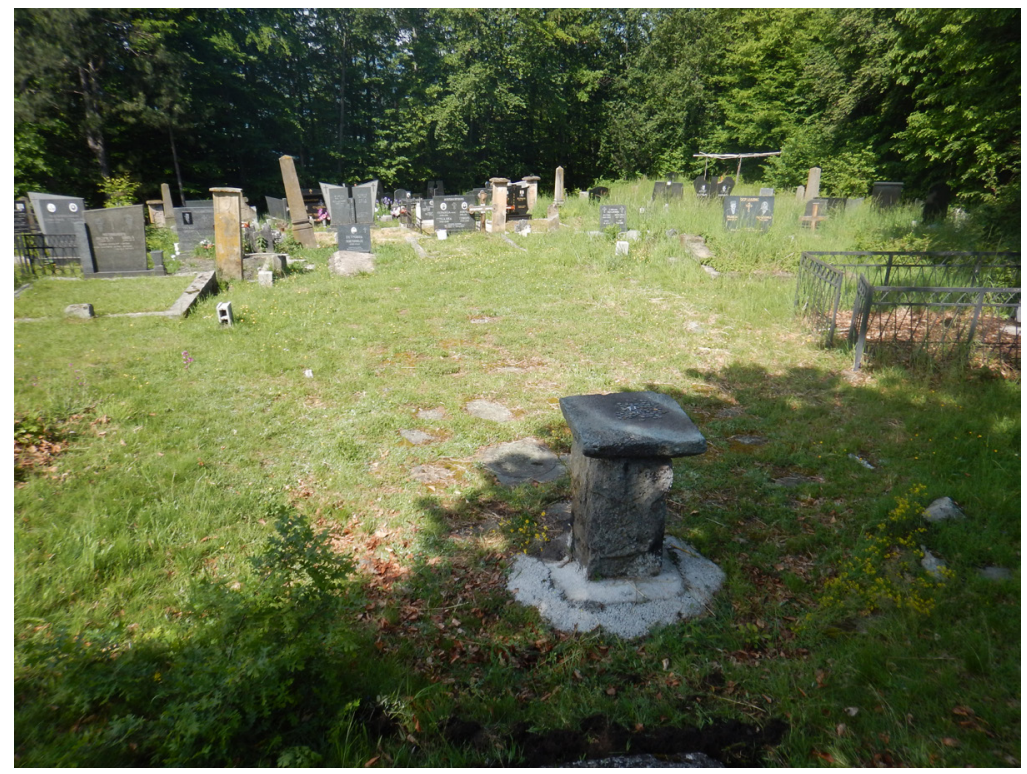

Сл. 9. Изглед цркве пре ископавања

Fig. 9. Appearance of the church before excavations

\footnotetext{
13 Локалитет се налази у власништву црквене општине Миланџа, на парцели бр. 1291/2, коју окружује сеоско гробље - бр. парцеле 1291/1.
} 
О самој цркви нема никаквих историјских или етнографских података. Није нам познат патрон храма или њен ктитор. Сеоска слава Св. арханђела Гаврила верујемо указује и на првобитну посвету храма.

Први помен села у историјским изворима налазимо у попису влаха Сјенице, у зеамету Барча, у поседу Синан-бега, где се нашло и село Сивча са 19 домова, за које претпостављамо да је данашња Сивчина (Aličić 2008, 26). У каснијим објављеним пописима нахије Моравица из друге половине 16. века и у опширном попису Босанског санџака из 1604. године, село се не помиње (Мушовић 1988, 163-172; Buzov i Gazić 2000). Нема га ни још у два необјављена пописа нахије Моравица из 1516/1517. године, односно 1549/1550. године. ${ }^{14}$ Поново га налазимо тек у попису из 1708 . године, под данашњим називом Сивчина, као махалу Доње Брезове. ${ }^{15}$ У међувремену, у већ помињаном Рачанском поменику насталом у 17. веку налазимо Драгића, Радоја и Сима из села Сивац, односно данашње Сивчине (Поменик манастира Раче 2005, 55a).

Убрзо након рекогносцирања, у периоду од 13. до 17. јула 2018. године извршена су археолошка истраживања Црквине. ${ }^{16}$ У унутрашњости цркве, када је уклоњено бусење траве, откривен је камени под, изведен од квадратних и правоугаоних камених плоча сивог и жућкастог кречњака (сл. 10). На средини храма, такође на каменом поду, формирана је неправилна цементна превлака, која представља остатак мешања бетона за изградњу околних гробница. У западном делу цркве у једној од обнова, већи део подних плоча замењен је квадратним плочама израђеним од жућкастог пешчара из каменолома у селу Луке код Ивањице. ${ }^{17}$ Мању и најкаснију интервенцију у поду представља накнадно и спорадично убацивање правоугаоних плоча, од сивог кречњака, прецизније израде са траговима штоковања. На поду према апсиди лежи правоугаона подна плоча са плитко урезаном кружном амвонском розетом, пречника 0,54 цм (сл. 11).

Од осталог мобилијара у цркви је затечена часна трпеза квадратне форме, димензија 0,60 х 0, 60 м, израђена од шкриљца, коју носи масиван камени постамент. Мештани су бетоном везали часну трпезу и постамент, те постамент такође причврстили за под дебљим слојем бетона.

\footnotetext{
14 TD 56, s. 41; TD 57, s. 22; TD 768. Захваљујемо др Срђану Катићу на још непубликованим преводима које нам је љубазно уступио на увид.

${ }^{15}$ MAD 4480, s. 24. Још увек непубликовани превод др Срђана Катића.

${ }^{16}$ Археолошка истраживања извео је Историјски институт у Београду. Руководилац истраживања био је археолог др Дејан Булић, научни сарадник Историјског института из Београда, док је цркву архитектонски снимио Александар Матовић, архитектонски техничар Завода за заштиту споменика културе из Краљева. Радну снагу чинили су мештани села Сивчина, заправо породица Раца Секулића и његови пријатељи.
}

17 О пореклу камена сведоче мештани. 


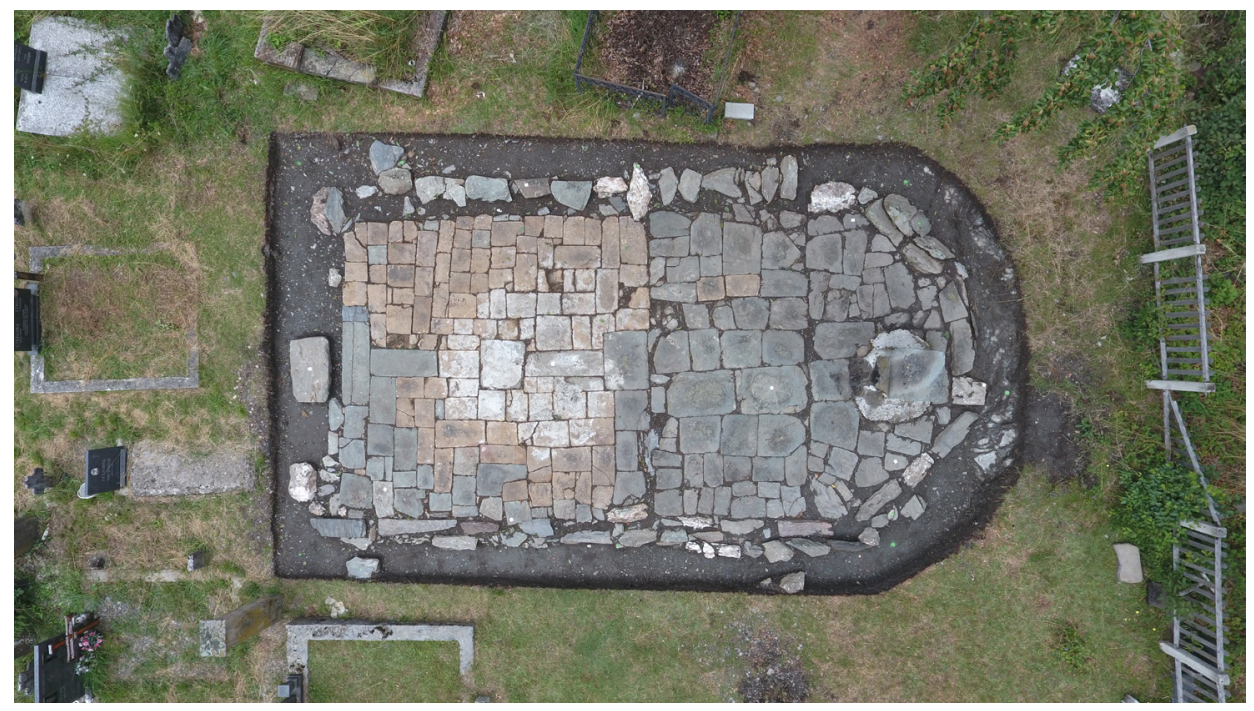

Сл. 10. Основа цркве (снимак дроном)

Fig. 10. Base of the church (drone shot)

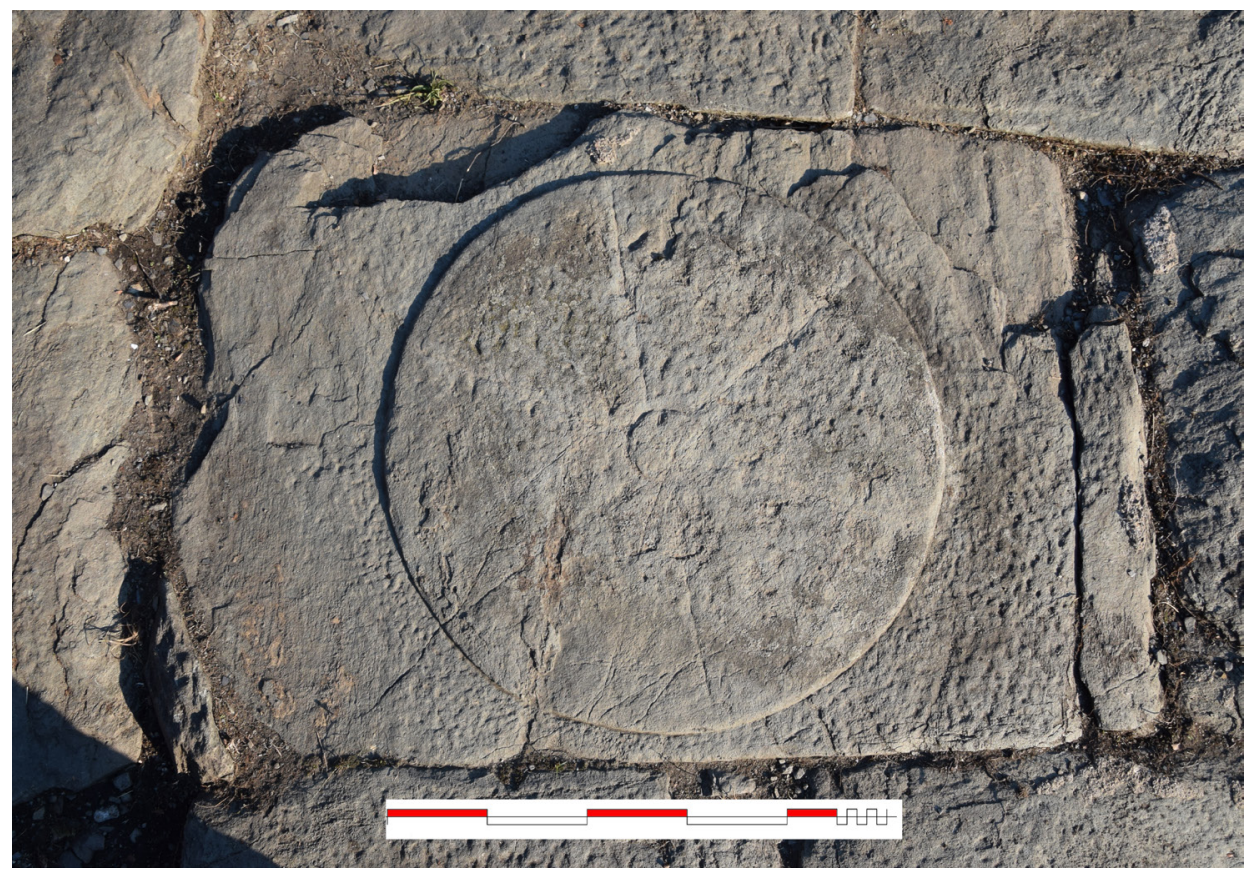

Сл. 11. Амвонска розета

Fig. 11. Ambon rosette 

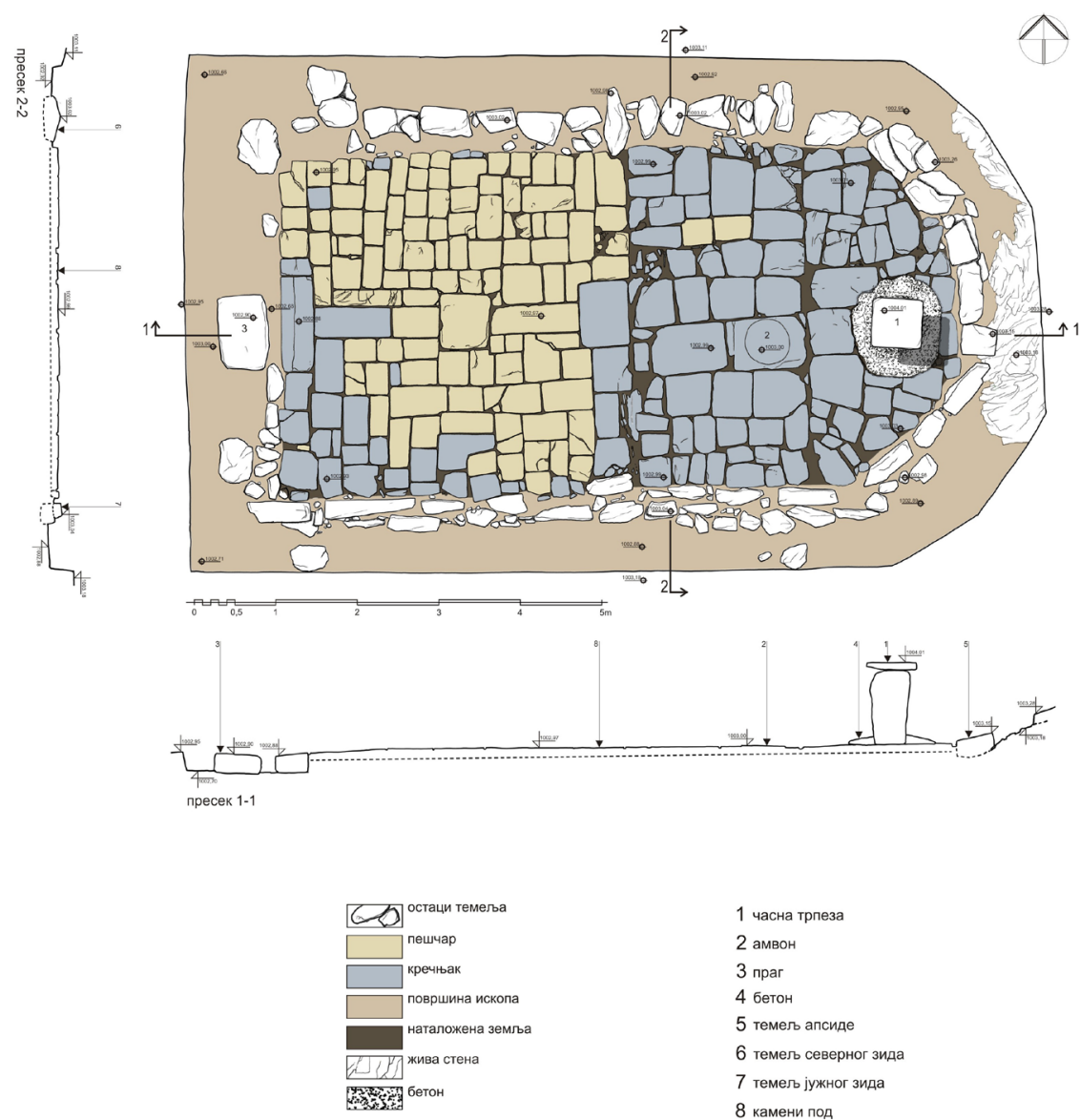

$$
\begin{aligned}
& 1 \text { часна трпеза } \\
& 2 \text { амвон } \\
& 3 \text { праг } \\
& 4 \text { бетон } \\
& 5 \text { темељ апсиде } \\
& 6 \text { темељ северног зида } \\
& 7 \text { темељ јужног зида } \\
& 8 \text { камени под }
\end{aligned}
$$

Сл. 12. Основа и пресеци цркве

Fig. 12. Base and cross-sections of the church

Црква је једнобродна грађевина, правоугаоне основе са тространом апсидом која се без рамена у пуној ширини брода развила на источној страни. Унутрашње димензије цркве брвнаре износе 8,20 x 4,20 м, на које треба додати дебљину зидова, па спољне димензије износе 9,40 х 5,20 м. Првобитни положај дрвене олтарске преграде види се на основу слога каменог пода, према коме је презвитерски део обухватао простор ширине 1,80 м. Оријентација цркве је И-3 са девијацијом од 20 степени ка северу (сл. 12).

Као што је и уобичајено код цркви брвнара, црква није имала укопаних темеља, већ су греде темељаче биле постављене на соклу формираном од камена сложеног у суво. На темељаче су потом слагане хоризонталне греде 


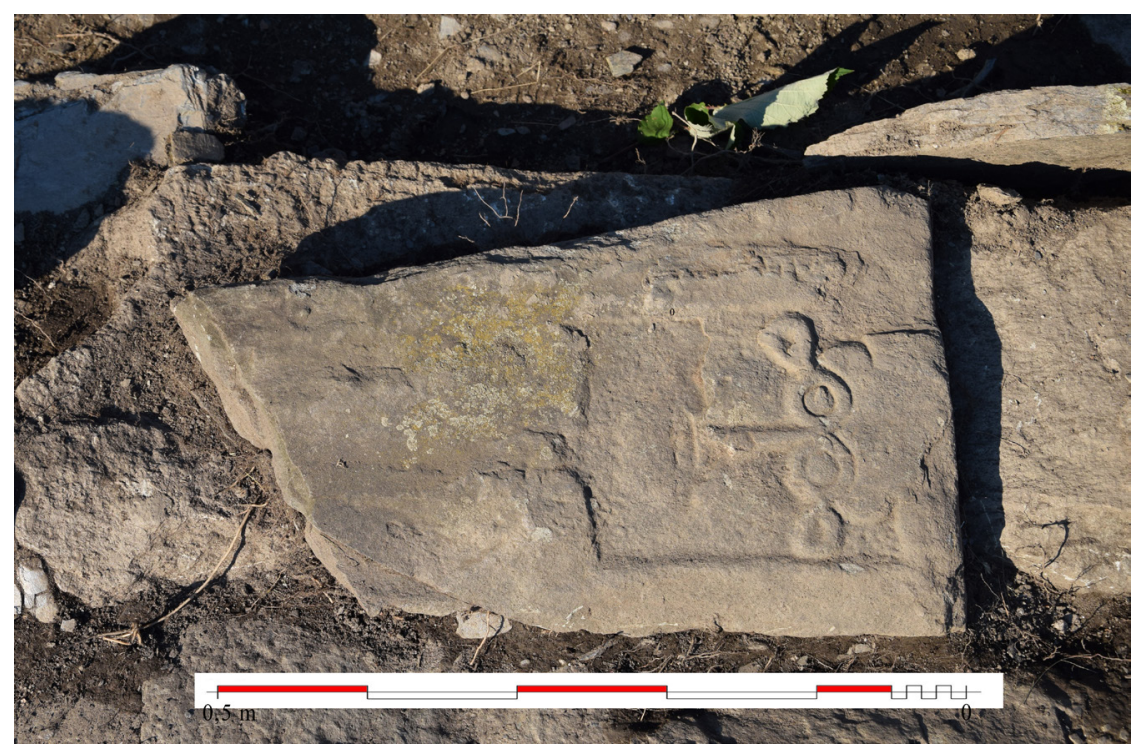

Сл. 13. Надгробни споменик из темеља цркве

Fig. 13. Tombstone from the foundations of the church

формирајући дрвене зидове. ${ }^{18}$ Са спољне стране темељачи био је поређан један ред камена, који је спречавао продирање воде. Уз апсиду, међу каменом употребљеним за ову функцију налазио се и један надгробни споменик са рељефном представом људског лика, у маниру раних студеничких споменика (сл. 13). Међутим, у овом случају није употребљен студенички мермер, већ локални шкриљац, што говори у прилог локалној изради надгробника, уз имитирање студеничког узора. Истовремено, овакав споменик израђен од шкриљца у маниру студеничке школе, колико нам је познато, представља први регистровани примерак овакве врсте. ${ }^{19}$ Овакав споменик није лако датовати, због непостојања директних аналогија, али пластичност лика указује на студеничке узоре 16-17. века. Рељефно представљени портрети ктитора и покојника припадају 16-17. столећу (Станић, 2007, 57-66; Премовић-Алексић, 2011, 471-486; Дудић, 1995, 36-37). Да је заиста реч о 16-17. веку, показује одсуство оваквих споменика међу корпусом надгробника 18. века из Студенице (Дудић, 1995, 366-385) и Петрове цркве (Поповић, 1984, 64-72). Очито је споменик настао у периоду када студенички надгробници нису

\footnotetext{
18 За технику градње цркава брвнара видети: Павловић, 1962, 58-75.

19 Да није једини, већ у ивањичком крају уобичајена појава, уверили смо се на сеоском гробљу у Братљеву, где је такође регистрована имитација студеничког надгробника у локалном камену, додуше, нешто млађе варијанте.
} 


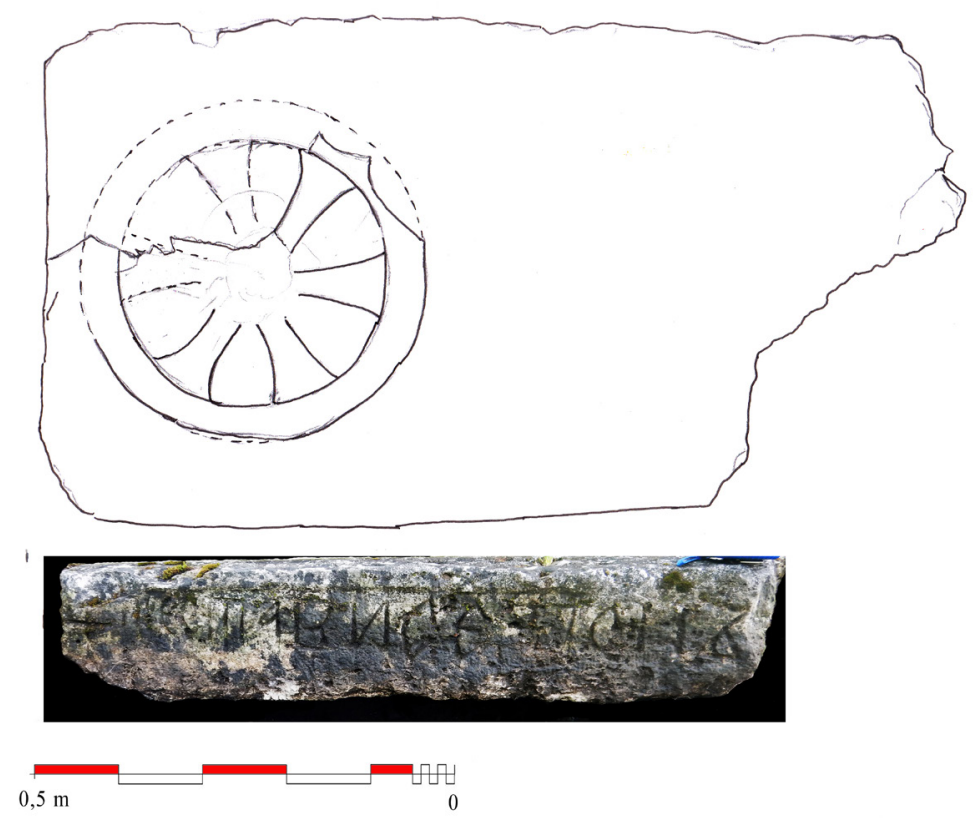

Сл. 14. Надгробна плоча са натписом

Fig. 14. Tombstone with an inscription

били тако чести у овом крају или када су били скупи, те недоступни појединим становницима Сивчине. Споменик је овде у секундарној употреби, али чињеница да је копија датира га у 17. или сам почетак 18. века.

Са североисточне источне стране, уз апсиду лежала је фрагментована надгробна плоча, сачуваних димензија 1,10 х 0,60 х 0,14 м (сл. 14). Првобитно место споменика је било северозападно од цркве, али је приликом ранијих интервенција на гробљу, премештен на садашњу позицију. ${ }^{20}$ Плоча на предњој страни има линеарно усечену представу точка, док је са бочне стране уклесан натпис, нажалост, само делимично сачуван: $\uparrow$ представи се раб божији поп у... Овакав орнамент, који у суштини представља астрални симбол, односно сунце, среће се на једној надгробној плочи из Студенице, где је описан као кружница издељена на сегменте (Поповић 2015, 385, Т. III/5). Неуобичајено је постављен натпис са стране споменика, а непостојање датираних аналогија онемогућава и његово прецизно датирање. Можемо да претпоставимо да је споменик временски близак изградњи цркве, оквирно другој половини 17. столећа.

\footnotetext{
${ }^{20}$ О дислокацији надгробика сведоче мештани, али се са сигурношћу не може прихватити његова првобитна позиција.
} 


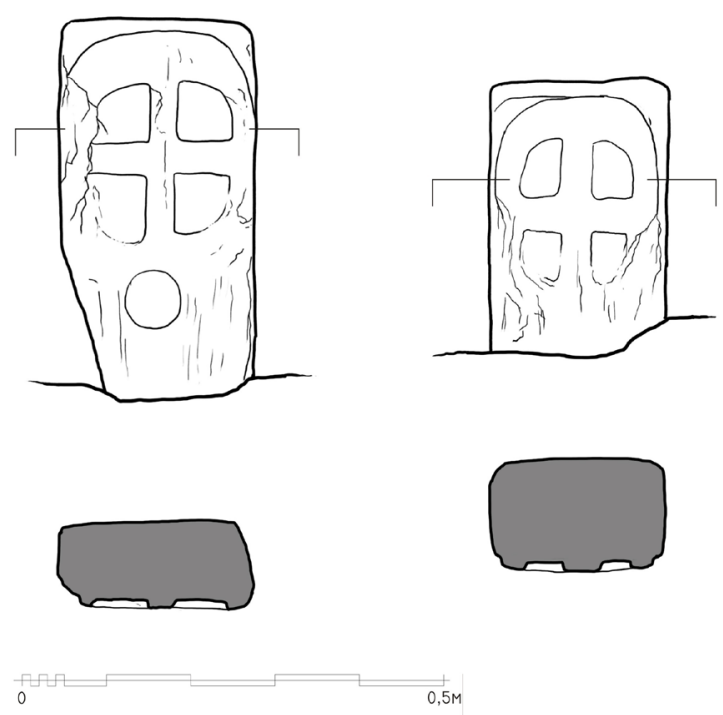

Сл. 15. Надгробни усадници

Fig. 15. Tombstones

Са јужне стране цркве леже два мања правоугаона усадника рађена од сивог кречњака. На предњој страни споменика налази се рељефна декорација крста у кругу, док је позадина издубљена (сл. 15). Један од споменика има и истурену представу постамента крста у виду кугле, односно представу крста на Голготи. Усадници представљају споменике најранијих сахрана уз постојећу цркву. Уз описану плочу најстарији су надгробници на гробљу, које се с временом формирало око црквеног храма. Компарације у третирању површине споменика налазимо на конзоли изнад лунете врата Цркве Св. Лазара у Живелићима, у сливу реке Људске код Новог Пазара, са уклесаном 1624-25. годином (Станић 1981, 152-153; Дудић 1995, 256.). Слично третирање површине налазимо и на надгробним споменицима из 17. и 18 . столећа уграђених као сполије у бастионе фортификације Београдске тврђаве (Поповић 2005, 213-226). Због тога их према аналогијама датујемо у крај 17. или пре у 18. столеће.

Цркву окружује гробље, са студеничким крстовима, крајпуташима и савременим надгробницима, међу којима је летимичним прегледом констатован најстарији надгробник са натписом из 1833. године. Истиче се и једна изузетна велика крстача из 1899. године са траговима плаве, црвене, сиве и беле боје. 

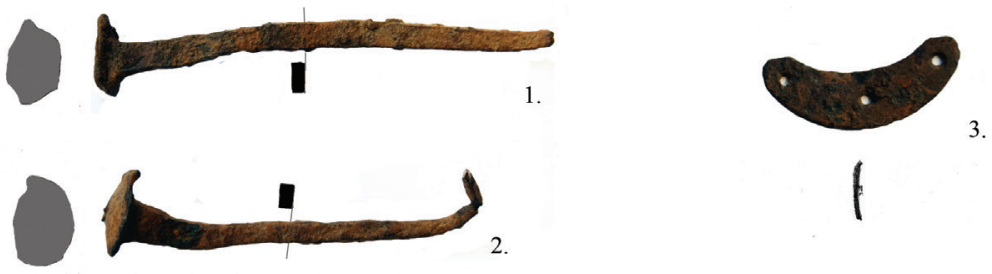

1

3.

2.
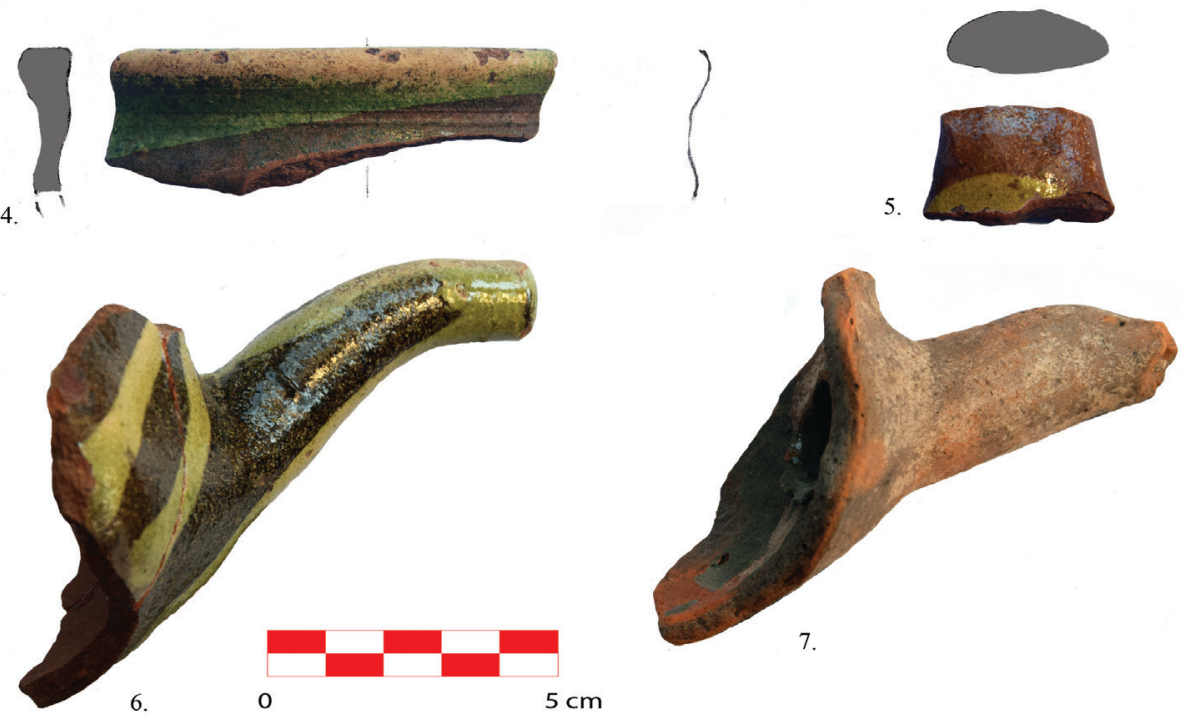

6.

$5 \mathrm{~cm}$
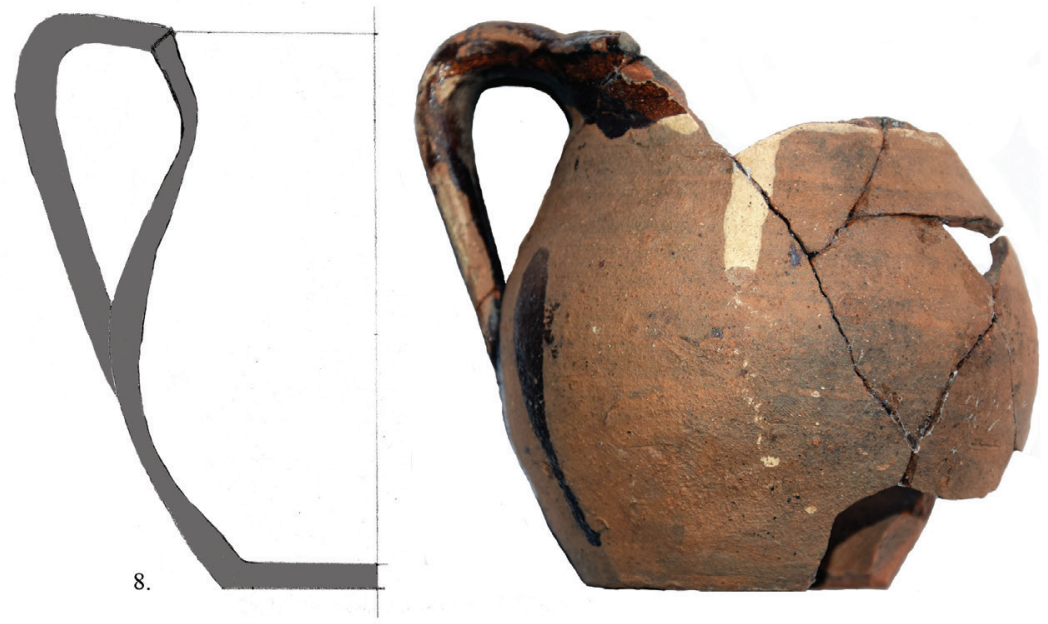

Сл. 16. Археолошки налази

Fig. 16. Archaeological findings 
Од покретних археолошких налаза пронађена су два гвоздена ексера - један уз спољни северозападни угао цркве и други уз северни зид, у зони где су код цркава брвнара северна врата. Такође, код улаза цркве, на нивоу пода, пронађен је један мањи блокеј за обућу (сл. 16). Спорадично је проналажен мањи број уломака керамике, у две зоне - уз северозападни угао цркве и уз спољно лице југоисточног полигона апсиде. Малобројни налази кованика и блокеја нису сами по себи хронолошки осетљиви. Кованици су вероватно припадали цркви и датују се у време њене изградње, док се блокеј ту могао наћи и након уништења црквеног храма. Пронађени керамички уломци представљају делове неколико мањих посуда народне грнчарије, које сведоче периоду коришћења цркве, и то њеној последњој фази трајања. Датирају се у 18. столеће и евентуално сам почетак 19. столећа.

Што се тиче датирања цркве, бројне аналогне цркве брвнаре подигнуте су током османске власти и често страдале у Аустријско-турском рату с краја 17. века.

Сличних димензија и истог изгледа је црква брвнара са Латинског гробља у Врсеницама, која је страдала крајем 17. столећа (Премовић-Алексић, 1997, 27-35; Премовић-Алексић, 2014, 581). ${ }^{21}$ Сличне основе је и црква на Грчком гробљу у Маринковићима (Поповић, 1991, 26; ПремовићАлексић, 2014, 207). Такође у исто време је страдала и црква брвнара из села Гоње, са лок. Црквина. ${ }^{22}$ Црква брвнара је и храм са сеоског гробља у Шароњама (Премовић-Алексић, 2014, 72), Буковцу (Премовић-Алексић, $2014,86)$, Тунова (Премовић-Алексић, 2014, 91). Поред поменутих цркава, пострадала је такође 1690. и црква из села Вапе (Поповић, 1996, 33-49; Премовић-Алексић, 2014, 531), док је у време Првог српског устанка пострадала црква у Избицама (Премовић-Алексић, 2014, 149).

Према археолошким истраживањима, аналогијама и надгробницима који је окружују, црква у Сивчини највероватније је подигнута у другој половини 17. столећа. Секундарно уграђени споменик у темељ цркве, израђен према студеничким узорима 16-17. столећа, датиран је у 17. столеће. Најстарији споменици су два мања усадника са јужне стране цркве и припадају самом крају 17. столећа, или вероватније 18. столећу. Поменути споменици су временски најближи настанку цркве и сведоче о већ постојећем црквеном храму.

Обнова пода цркве чак у два наврата сведочи о дуготрајној употреби храма и њеним страдањима. Без поузданих историјских података, за страдање

\footnotetext{
${ }^{21}$ Премовић-Алексић, 1997, 27-35.

22 Документација Завода за заштиту споменика културе Краљево са археолошких ископавања цркве брвнаре из села Гоње, под руководством Гордане Гаврић.
} 


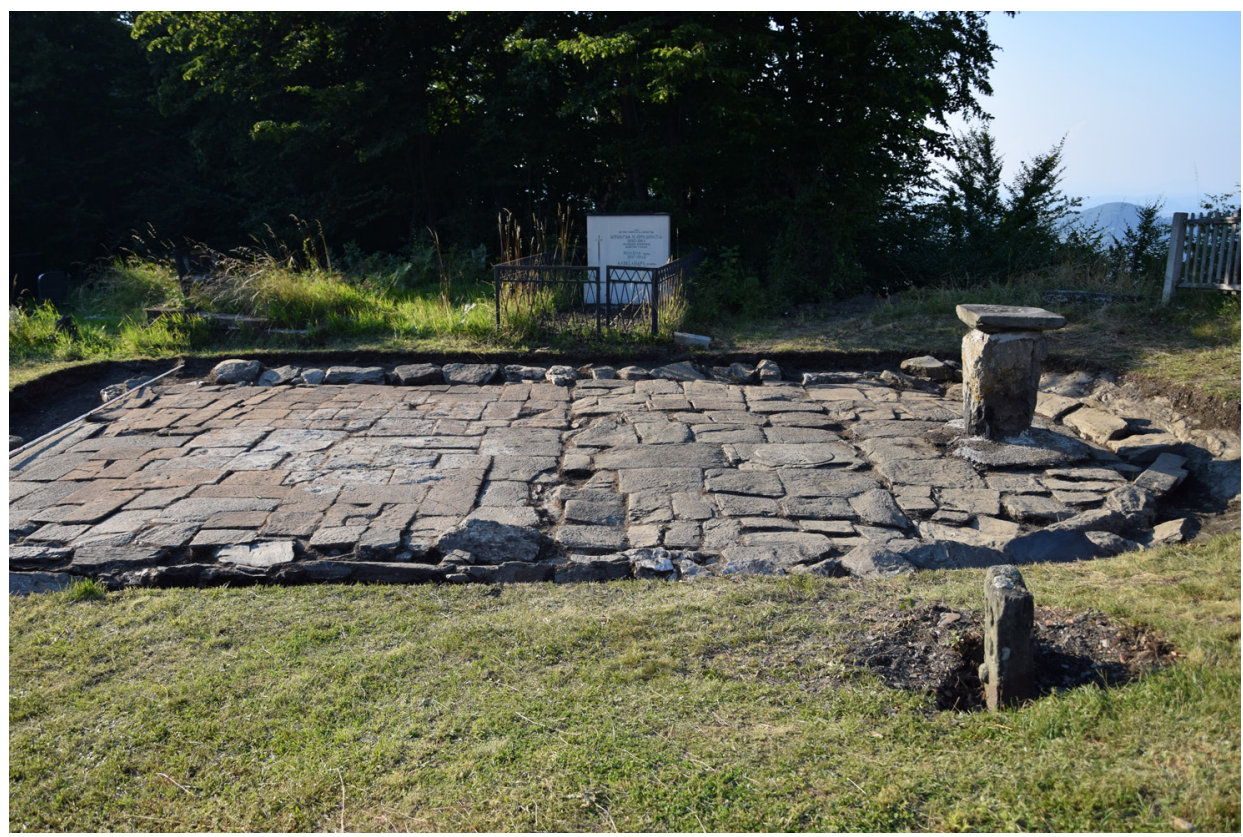

Сл. 17. Изглед цркве након ископавања (снимак са југа)

Fig. 17. Appearance of the church after excavations (photo from the south)

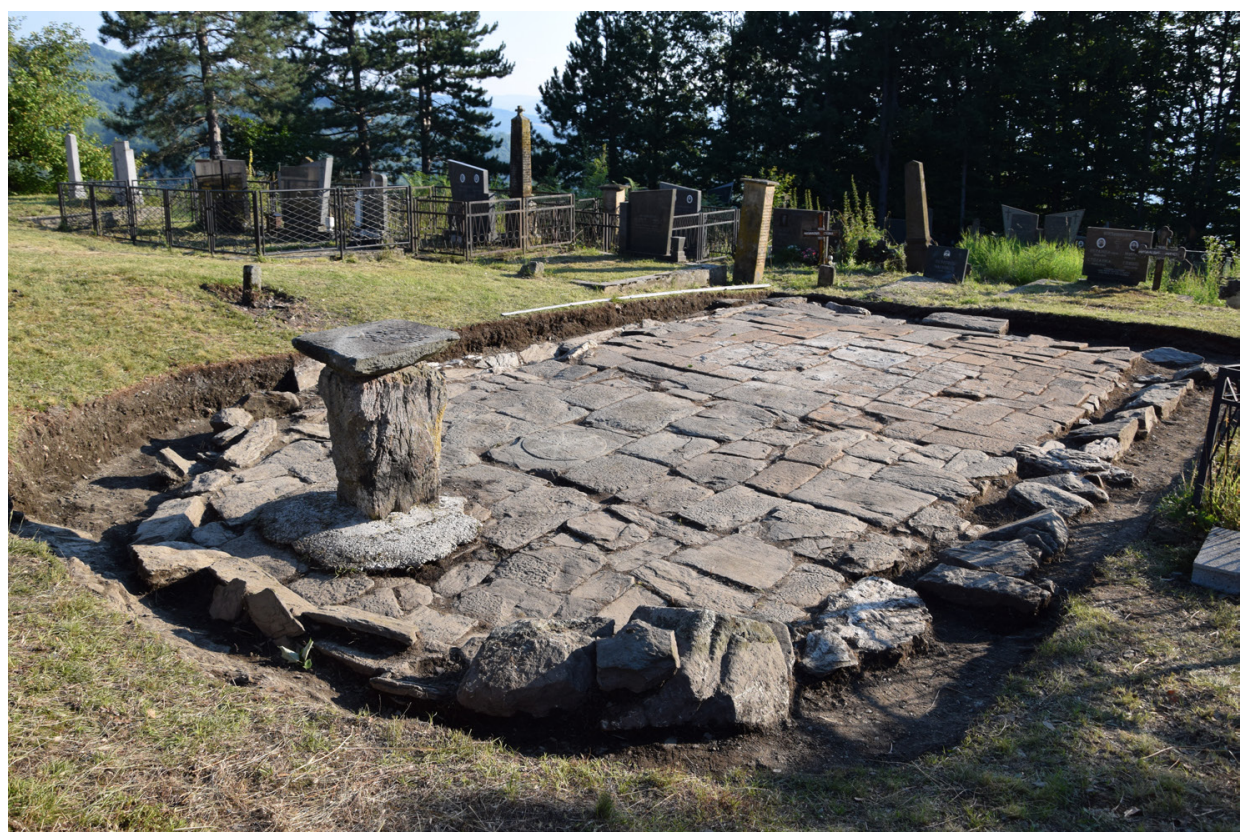

Сл. 18. Изглед цркве након ископавања (снимак са североистока)

Fig. 18. Appearance of the church after excavations (photo from the north-east) 
цркве, након кога је уследила обнова, намеће се 1690. година, као и 1737-1739. и време аустријско-турских ратова. Коначан крај цркве видимо у годинама слома Првог српског устанка, када су и бројне цркве у околини страдале. ${ }^{23}$ Тешко да је реч о нешто каснијем периоду јер не постоји народно сећање на време страдања цркве, што би требало да се очувало у случају неке ближе историје. Пронађени уломци грнчарије потцртавају време 18. и почетка 19. столећа и последње године употребе храма и његово коначно страдање.

Црквени храм у Сивчини спада у ретку групу на тлу ивањичке општине који је стручно истражен и документован (сл. 17 и 18).

О црквама у Заглавку и Сивчини немамо готово никаквих историјских података. Иако не знамо патроне храма, имена ктитора и неимара, ова чињеница као и градитељске карактеристике снажно сугеришу услове у којима су настали црквени храмови. Начин градње и употреба јефтинијих материјала указују на чињеницу да су зидане у тешким околностима, када политичке и економске прилике нису ишле наруку градитељима.

То се нарочито уочава код цркве из Заглавка, где је градитељ користио искуства профане градње сеоских грађевина. Градитељска техника подразумева употребу локалног камена и земље као везива, рециклирајући материјал са старих античких објеката, који, иако уобичајен, ипак је дефицитаран. Мада не треба искључити и могућност да се употреба античких опека доводи у везу и са погрешним веровањем да потичу са некадашњих цркава, како се често остаци античких вила перципирају. Друга црква из Сивчине користи најбоља искуства градње брвнара и обраде камена на простору данашње Ивањице.

Презентоване грађевине носе обележја колико самосвојна толико и типична за неимаре свога времена и краја. Представљају прави одраз прилика у којима су настале, као творевине локалних мајстора и локалних градитељских техника, на најбољи начин осликавају моћ ктитора и фолколорне градитељске традиције. Настале из потребе за физичким и духовним самоодржањем две сеоске заједнице у тешким временима, далеко су од некадашњег сјаја српског средњовековног стваралаштва и репрезентативних храмова османског доба. У посебним историјским условима, представљају вредна градитељска остварења - прожета народним духом - која су одиграла пресудну улогу у очувању духовног бића народа.

${ }^{23}$ О страдању цркава и манастира видети: Марковић 1999, 319-331. 


\section{БИБЛИОГРАФИЈА}

Aličić, A. 2012. Sumarni popis sandžaka Bosna iz 1468/69. godine, Mostar: Islamski kulturni centar.

Başbakanlık Osmanlı Arşivi, Istanbul, Tapu Tahrir Defterleri (TD): TD 56, s. 41; TD 57, s. 22; TD 768.

Buzov, S. i Gazić, L. 2000. Opširni popis bosanskog sandžaka iz 1604. godine, II, Sarajevo: Bošnjački institut Zurich, Odjel Sarajevo; Orijentalni institut u Sarajevu.

Вукадин, О. и Ивковић, 3. 1987. Духовни и материјални остащи рујанског манастира, У3 16: 81-89. Ужице: Историјски архив.

Дудић, Н. 1995. Стара гробља и надгробни белези у Србији. Београд: Републички завод за заштиту споменика културе; Просвета.

Ђорђевић, М. 1996. Бела Црква - Каран, археолошка истраживања у припрати 1995. године, Гласник Друштва конзерватора Србије 20: 104-107.

Ивковић, 3. и Ђокић, М. 1988. Брезова, црква св. Николе, Рашка Баштина 3: 317-318. Јанковић, Ђ., и Праштало, П. 2008. Археолошко истраживање на локалитетима Лађевац - Скит Св. Ђорђа и Градина код Бајине Баште, Археолошки преглед 4 н. с.: 143-145.

Мандић, М., Мандић, Љ. и Ђурић, Ј. 2002. Прелиминарни извештај о заштитним археолошким истраживањима на локалитету Савинац, у селу Висибаба, СО пожега, Извршеним од 5. јуна до 14. јула 2001. године, Пожешки годишњак 2: 13-20.

Марковић, Ж. 1999. Ужички крај у доба Карађорђа. Пожега: Народна библиотека Пожега.

Мушовић, Е. 1988. Нахија Моравица (Ивањица) у XVI веку. Симпозијум сеоски дани Сретена Вукосављевића 12: 163-172. Пријепоље: СИЗ културе; Дом револуције у Пријепољу.

Павловић, Љ. 1930. Соколска нахија, Насеља и порекло становништва, књ. 26. Београд: Српска краљевска академија.

Павловић, Д. 1962. Цркве брвнаре у Србији, Саопштења V, Београд: Републички завод за заштиту споменика културе.

Поменик манастира Раче, 2005. приредио Томислав Јовановић. Бајина Башта: Фондација Рачанска баштина.

Поповић, Д. 1984. Надгробни споменици из цркве Светог Петра код Новог Пазара, Новопазарски зборник 8: 51-75.

Поповић, Д. 1996. Старо гробље у Вапи код Сјенице, Новопазарски зборник 20: 33-50.

Поповић, Д. 2015. Средњовековне надгробне плоче у Студеници, у М. Поповић, Манастир Студенища:археолошка открића, 381-394. Београд: Републички завод за заштиту споменика културе; Археолошки институт.

Поповић, М. 1995. Ужички град, Београд: Археолошки институт; Ужице: Историјски архив Ужице. 
Поповић, М. 2005. Трагови једне београдске некрополе 17. века, Наслеђе 6: 213-226. Премовић-Алексић, Д. 1997. Латинско гробље у Врсеницама, Новопазарски зборник 21: 27-35.

Премовић-Алексић, Д. 2011. Прилог проучавању скулпторалних портрета ктитора у околини Новог Пазара, Зборник Народног музеја XX-1: 471-486.

Премовић-Алексић, Д. 2014. Археолошка карта Новог Пазара, Тутина и Сјенице, Нови Пазар: Музеј „Рас”.

Радосављевић, Н. 2000. Ужичко-ваљевска митрополија 1739-1804. Ваљево: Историјски архив.

Руварац, Д. 1924. Манастир Беочин. Сремски Карловци: Српска манастирска штампарија.

Станић, Р. 1981. Један облик стварања у сливу реке Људске код Новог Пазара, $\mathrm{Ca}$ опитења 13: 143-161.

Станић, Р. 1993. Црква Светог Николе у Брезови код Ивањице, Cаопштења 25: 97-145.

Станић, P. 2007. Скулпторални портрети ктитора и мајстора на црквама XV-XVII века у западној Србији и Санџаку, Одабрани радови, Београд: Републички завод за заштиту споменика културе: 57-66.

Тошић, Т. 1997. Манастир Ковиље - археолошка истраживања, Гласник Друштва конзерватора Србије 2: 96-97.

Трећа војна мапа Аустроугарске - Zvornik 37-44. Генералне мапе централне Европе, размера 1:200.000, 1913. Извор: https://commons.wikimedia.org/w/index. php?title=Category:3rd_Military_Mapping_Survey_of_Austria=Hungary\&filefromReczyca+-+48-52.jpg\#/media/File:Zvornik_-_37-44.jpg. Приступљено 30. 05. 2020. године.

Цветковић-Томашевић, Г. 1990-1991. Бела црква у Карану - маузолеј жупана Брајана, Археолошка ископавања у цркви 1975. године, Саопштења 22-23: 159-176.

Цуњак, М. и Јордовић, Ч. 1982. Некропола цркве Св. Ахилија у Ариљу, Саопштена 14: 231-241.

Чанак-Медић, М. 2002. Свети Ахилије у Ариљу, Београд: Републички завод за заштиту споменика културе. 


\title{
Dejan Bulić
}

Institute of History, Belgrade

\section{TWO CHURCHES FROM THE OTTOMAN PERIOD IN WEST SERBIA}

\author{
Keywords: West Serbia, Zaglavak, Sivčina, Ottoman period, \\ church, $17^{\text {th }}$ century, Bajina Bašta, Ivanjica
}

In 2018, the Institute of History performed archaeological researches on two churches from the Ottoman period. The first one is located in the village of Zaglavak, near Bajina Bašta, on loc. Orašac. The church is a one-nave building with a rectangular basis and a semi-circular apse on the eastern side, with outer dimensions of $9.60 \mathrm{~m} \times 6 \mathrm{~m}$ (T. 1). It was built in a modest and inattentive manner, with local, broken stone, without regular rows being formed. Yellow clay was used as a binding material, without the addition of mortar. The maximal preservation of the walls is three to four rows of stone, or $0.69 \mathrm{~m}$.

The floor of the church was made of compacted earth. Traces of the floor were preserved only in the apse, under a layer of collapsed tufa, where a thin layer of clayish red earth was registered. The findings of tufa bear witness on the material used to make the semi-calotte of the apse, while fragments of tegulae inside the apse indicate that the roof of this church had been covered with antique tegulae.

Due to a lack of any mobile archaeological findings, a clearly formed floor and the circumstance that a necropolis hadn't been formed around the church, it was deduced that the church was in use for a short period of time. On the basis of archaeological researches and the mention of a priest in the Račanski pomenik, the church was most probably built just before the last decade of the $17^{\text {th }}$ century, and it was destroyed already during the Great Migration of the Serbs in 1690. The church was built in the traditional technique, in the spirit of popular building systems, with the use of broken stone and clay as a binder, which would suggest a local ktetor and local craftsmen.

The second church is located on the site of Bare in the village of Sivčina, ten kilometres to the west from Ivanjica. After the Turkish conquest, it was in the area of the Sanjak of Bosnia, within the Nahiyah of Moravica. The patron saint of the village Saint Archangel Gabriel, we believe, could probably be the saint to whom the church was consecrated.

The church is a log-building, with one nave, rectangular basis, and a threesided apse, which spread along the full length of the nave, on the eastern side. The 
outer dimensions of the church are $9.40 \mathrm{~m} \times 5.20 \mathrm{~m}$. The original position of the wooden altar septum can be seen on the basis of the layout of the stone floor, according to which the presbytery comprehended an area which was $1.80 \mathrm{~m}$ wide.

According to archaeological researches, analogies and tombstones which surround it, the church was dated into the second half of the $17^{\text {th }}$ century. The restoration of the floor of the church on two occasions bears witness on it being demolished, and the final destruction of it can be traced into the years when the First Serbian Uprising collapsed, when numerous churches in its vicinity were also destroyed.

There are almost no historical data on the churches from Zglavak and Sivčina. The construction manner and use of cheap materials indicate the fact that they were built in difficult circumstances, when political and economic situation weren't favourable for the builders. They represent a true reflection of the circumstances in which they were built, as creations of local craftsmen and local building techniques, and they depict, in the best manner possible, the power of their ktetors and folk building traditions. 

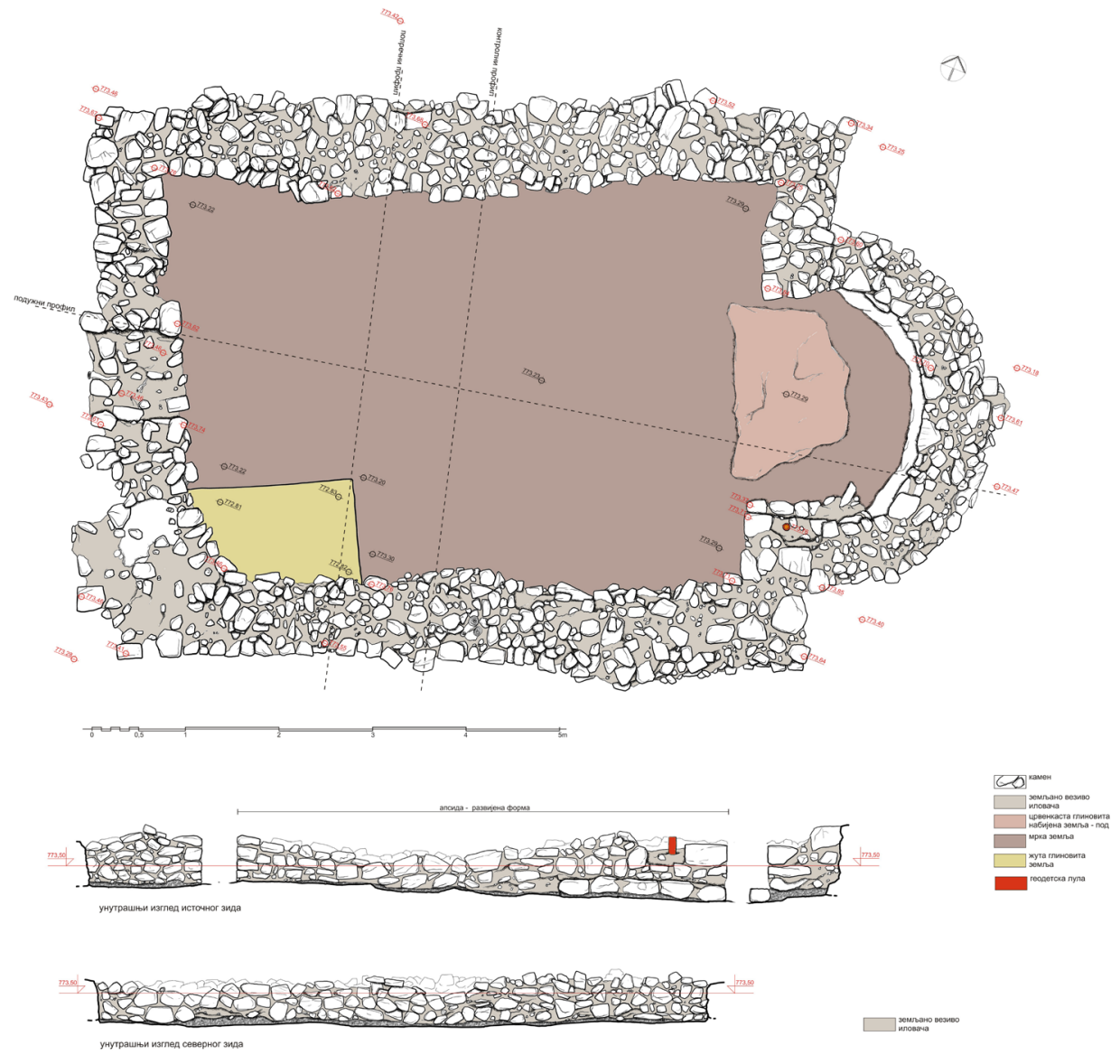

T. I Основа цркве и изглед зидова

PI. I The base of the church and the appearance of the walls 